\title{
THE EVALUATION OF THE ENERGY EFFICIENCY OF DAIRY FARMS WITH FREESTALL AND LOOSE HOUSES IN KONYA SUGAR INDUSTRY AND TRADE INC., TURKEY
}

\author{
Abdülkadir Serdar Onal ${ }^{1}$, Selda Uzal Seyfi ${ }^{2 *}$ \\ ${ }^{1}$ Konya Sugar Industry and Trade Inc., Konya, 42003, Türkiye; \\ ${ }^{2 *}$ Selcuk University, Agricultural Faculty, Farm Structure and Irrigation Department, 42021, Turkey; \\ "Corresponding author Selda Uzal Seyfi, e-mail: seldauzal@ selcuk.edu.tr;
}

Received February 2019; Accepted March 2019; Published April 2019;

DOI: https://doi.org/10.31407/ijees9202

UOI license: http://u-o-i.org/1.01/ijees/49540566

\begin{abstract}
Energy use is indispensable for sustainable agricultural production. Determination of energy use efficiency is pivotal for the productivity of dairy farms. In recent years, the Konya Region has the highest milk production and the greatest number of animals in Turkey. The dairy farms owned by the Konya Sugar Industry and Trade Inc (ITI) are the biggest farms in the Konya region and are run by entrepreneurs and leaders in livestock breeding. For this reason, it is important to evaluate the energy efficiency of these farms, for the development of animal breeding in the region and country. This study was carried out between 2017 and 2018, to evaluate energy use of the dairy farms of the Konya Sugar ITI. The company owns the Şekersüt Dairy Farm (SDF) with 7600 animal-capacity and the Çumpaş-Danabank Dairy Farm (CDF) with 1000 animal-capacity. Loose and freestall dairy houses are used on the farms. These farms were assessed for their energy use efficiency, net energy yield, specific energy, and energy productivity parameters. Consequently, energy productivity and energy use efficiency for SDF and CDF were calculated to be $3.6 \mathrm{~L} / 100 \mathrm{MJ}$ and 0.11 , and $5.2 \mathrm{~L} / 100 \mathrm{MJ}$ and 0.16 , respectively. Increased energy efficiency will be possible by determining the high-energy use efficiency value for other dairy farms in the research area and developing the applications accordingly, with this goal. Furthermore, it is also recommended that the dairy farm management is redesigned or improved to create a new barn design that is appropriate for animal welfare and high milk yield.
\end{abstract}

Keywords: Energy efficiency, Energy productivity, Net energy yield, Specific energy, Energy Saving 